\title{
Evaluation of Zinc Solubilizing Potential of Maize Rhizosphere Bacterial Isolates
}

\author{
Mangala Devi Perumal $^{1 *}$, V. Subramanian ${ }^{1}$ and K.G. Sabarinathan ${ }^{2}$ \\ ${ }^{1}$ Department of Soil Science and Agricultural Chemistry, ${ }^{2}$ Department of Agricultural \\ Microbiology, Tamil Nadu Agricultural University, Coimbatore, Tamil Nadu, India \\ *Corresponding author
}

\begin{tabular}{|l|}
\hline Key w o r d s \\
Solubilizing, Maize, \\
Bacterial isolates. \\
\hline Article Info \\
\hline $\begin{array}{l}\text { Accepted: } \\
07 \text { October } 2017 \\
\text { Available Online: } \\
10 \text { December } 2017\end{array}$ \\
\hline
\end{tabular}

Keywords

Solubilizing, Maize, Bacterial isolates.

Article Info

Accepted:

Available Online:

\section{A B S T R A C T}

Zinc is an essential micronutrient which plays a macro role in the growth and productivity of the plants. Generally Indian soils are low in $\mathrm{Zn}$ and as much as half of the country soils are categorized to be $\mathrm{Zn}$ deficient. Hence, zinc fertilizer is applied in the soil as zinc sulphate. However the major portions of applied zinc sulphate become unavailable to plant in the soil. There was six zinc solubilizing bacterial strains were isolated from rhizosphere of maize. The bacterial isolate ZSB SM-1 was found to be effective in solubilizing the insoluble zinc substances viz., zinc oxide, zinc carbonate and slowly soluble $\mathrm{Zn}$-EDTA. The insoluble $\mathrm{Zn}$ substance was effectively solubilized at 0.1 per cent concentration, compared to 0.2 per cent concentration. The solubilization might be due to production of acids by the culture, since the $\mathrm{pH}$ of the broth has been shifted from 7.0-7.3 to 3.0-4.8 after 10 days of inoculation.

\section{Introduction}

Micronutrients are important component for the growth of plants, animals and microbes. Among the micronutrients, Zinc is essential for the normal healthy growth and reproduction of plants, animals and humans and when the supply of plant-available zinc is inadequate, crop yields are reduced and the quality of crop products is frequently impaired. In plants, zinc plays a key role as a structural constituent or regulatory co-factor of a wide range of different enzymes and proteins in many important biochemical pathways and these are mainly concerned with: carbohydrate metabolism, both in photosynthesis and in the conversion of sugars to starch, protein metabolism, auxin metabolism, pollen formation. Zinc deficiency is identified as the most common occurring micronutrient problem in many parts of the country on a wide range of soil types.

In India, it has been estimated that more than 50 per cent of the soils are $\mathrm{Zn}$ deficient (Singh et al., 2005) and is predominant in the semiarid tropical soils.

Maize is one of the most important high value cereals consumed in many countries. The crop is widely grown in semi-arid tracts of India, 
which is characterised by extreme variation in rainfall pattern both in time and space. Besides this, the major constraint to sustainable maize production is the poor soil fertility. A bacterial based approach was devised to solve the micronutrient deficiency problem in cultivated soils. Among the bacterial species strains belonging to the genera Acinetobacter, Bacillus, Pseudomonas, Glucanoacetobacter have been reported (Sharma et al., 2012) Since $\mathrm{Zn}$ is a limiting factor in maize crop production, this study on zinc solubilization by bacteria has immense importance in zinc nutrition of maize crop.

\section{Materials and Methods}

\section{Collection of soil samples}

Soil samples were collected from seven different maize fields in and around Thoothukudi district, Tamil Nadu, India. Samples were randomly collected from the rhizosphere of young plants at a depth of 6-15 $\mathrm{cm}$. then the soil samples were used for isolation.

\section{Isolation and purification of zinc solubilizers}

Isolation of zinc solubilizing bacteria present in the maize rhizosphere soil samples were done by serial dilution plate count method using carbon rich Tris-minimal salt medium (Fasim et al., 2002). The carbon rich agar medium containing insoluble zinc compounds such as zinc carbonate, zinc oxide and slowly soluble zinc EDTA was used to select the bacterial isolates possessing zinc solubilizing ability. The petriplates were incubated at room temperature $\left(30 \pm 1{ }^{\circ} \mathrm{C}\right)$ for three days and the colonies exhibiting clear zones were selected, purified by four way streak plate method. The diameter of zone of solubilization was measured and the selected isolates were preserved on agar slants for further use.

\section{Solubilization of insoluble $\mathrm{Zn}$ compounds - Plate assay}

The medium used to assess the zinc solubilizing ability of bacteria in the study was Tris-minimal salt medium. The medium was prepared by incorporating insoluble $\mathrm{Zn}$ sources zinc oxide $(\mathrm{Zn} \mathrm{O})$, zinc carbonate $\left(\mathrm{ZnCO}_{3}\right)$, and slowly soluble Zinc-EDTA (Zinc-Ethylene Diamine Tetra Acetate) at 0.1 $\%$ and $0.2 \%$ with the carbon source glucose at $10 \%$. The $\mathrm{pH}$ was adjusted to 6.0 after sterilization, with sterilized medium was added to petriplates. Care was taken for uniform distribution of the insoluble zinc source into the petriplates and the plates were prepared without air bubbles. The agar plates were allowed to cool and $10 \mu \mathrm{l}$ of bacterial $\left(6 \times 10^{6} \mathrm{cfu} \mathrm{ml}^{-1}\right)$ suspension was placed on the agar surface. After placing the culture on the agar surface, the plates were kept undisturbed for $10 \mathrm{~min}$ to get absorbed in the agar medium without spreading. Then the plates were incubated at $29{ }^{0} \mathrm{C} \pm 1{ }^{0} \mathrm{C}$ and observed for solubilization zones up to 5 days. The diameter of the solubilization was measured and expressed in $\mathrm{cm}$. Two replicates were maintained for each treatment.

\section{Determination of soluble zinc content (Broth assay)}

The bacterial isolates were inoculated separately to Tris-minimal salt medium supplemented with $0.1 \%$ insoluble zinc compounds. The solubilization of zinc from laboratory grade $\mathrm{ZnO}, \mathrm{ZnCO}_{3}$ and $\mathrm{Zn}$-EDTA by ZSB was assessed. Tris-minimal salt medium (D-glucose -10 g; Tris HCl- $6.06 \mathrm{~g}$; Sodium chloride-4.68 g; KCl- $1.49 \mathrm{~g} ; \mathrm{NH}_{4} \mathrm{Cl}$ - $1.07 \mathrm{~g} ; \mathrm{Na}_{2} \mathrm{SO}_{4}-0.43 \mathrm{~g} ; \mathrm{MgCl}_{2} .2 \mathrm{H} 2 \mathrm{O}-0.2 \mathrm{~g}$; $\mathrm{CaCl}_{2} \cdot 2 \mathrm{H}_{2} \mathrm{O}-30 \mathrm{mg}$; Distilled water-1000 ml; $\mathrm{pH}-7$ ) was prepared, splitted in $50 \mathrm{ml}$ aliquots 
in $100 \mathrm{ml}$ Erlenmeyer flasks and $0.1 \%$ of insoluble Zn-compound added, steam sterilized for 30 minutes in an autoclave. Then the flasks were inoculated with $1 \mathrm{ml}$ suspension of the test culture with a cell load of $10^{7}$ cells $\mathrm{ml}^{-1}$. Three flasks were maintained with an uninoculated control for each treatment. Experiments were done in triplicate. The samples were withdrawn at 0 , $4,8,12$ and 16 days intervals, centrifuged to remove the debris and cells. Ten $\mathrm{ml}$ of this solution was fed to Atomic Absorption Spectrophotometer (AAS) to determine the soluble zinc content.

\section{Determination of $\mathbf{p H}$}

The $\mathrm{pH}$ of the zinc solubilizing bacteria (ZSB) culture filtrates and the uninoculated sample was determined at $0,24,36,48,72$, 96 and $120 \mathrm{hrs}$ after inoculation. The culture was filtered using Whatman No.1 filter paper. The $\mathrm{pH}$ was estimated using $\mathrm{pH}$ meter (Elico $\mathrm{pH}$ meter).

\section{Zinc tolerance by ZSB isolates}

Zinc is a nutrient at low concentration but toxic at higher concentration. The solubilization of zinc might limit the growth of the bacteria at higher level. Unless the cultures tolerate a higher level of zinc, its solubilization may not continue. Therefore the ability of selected isolate to tolerate solubilized zinc was determined under in vitro condition in nutrient broth containing different concentrations of soluble zinc $\left(\mathrm{ZnSO}_{4}\right)$. The nutrient broth was prepared and splitted in $100 \mathrm{ml}$ aliquots in Erlenmeyer flasks. The $\mathrm{ZnSO}_{4}$ was incorporated into the broth in such a way that the final concentration of zinc was $25,50,100,200$, 300,400 and $500 \mathrm{mg} \mathrm{kg}^{-1}$. These solutions were divided into $10 \mathrm{ml}$ quantities in test tubes, sterilized at 15 psi for 15 minutes and inoculated with $0.1 \mathrm{ml}$ of ZSB. An uninoculated control was also maintained. The total ZSB population was assessed by plating on Tris-minimal salt medium. The growth of bacteria in the zinc containing medium indicated their tolerance to zinc.

\section{Results and Discussion}

There are six isolates were isolated from maize rhizospher soil. These selected isolates were identified based on their morphological and biochemical characters test. The zinc solubilization potential of ZSB cultures in different concentration of insoluble zinc with glucose as carbon source was assessed. The results are presented in Figure 1. The six cultures (ZSB SM-1, 2, 3, 4, 5, 6) established growth at both 0.1 per cent and 0.2 per cent concentration of $\mathrm{ZnO}, \mathrm{ZnCO}_{3}$ and $\mathrm{Zn}$ EDTA. Among the zinc concentrations, 0.1 percent supported more solubilization compared to 0.2 per cent irrespective of carbon sources and cultures. Among the cultures tested, ZSB SM-1 showed higher solubilization.

Maximum solubilization was observed at 0.1 per cent $\mathrm{ZnO}$ in glucose medium $(4.2 \mathrm{~cm})$ by ZSB SM-1. The solubilization on Zn-EDTA supplemented medium was comparatively less. With glucose as carbon source at $0.1 \%$ zinc concentration, ZSB SM-1 exhibited the solubilization zone of $4.2,3.8$ and $2.5 \mathrm{~cm}$ with zinc oxide, zinc carbonate and zinc EDTA, respectively. Zinc tolerance potential also varied with isolates ZSB SM-1 and ZSB SM-3 (Table 1). The ZSB SM-1 culture had shown a cell count of $1 \times 10^{4}$ on the $8^{\text {th }}$ day after inoculation in a 500 mg $\mathrm{kg}^{-1}$ concentration of zinc, whereas the ZSB SM-3 was completely inhibited at $500 \mathrm{mg} \mathrm{kg}^{-1}$ concentration after 8 days of inoculation. Based on the solubilization zone ZSB SM-1 used to further experiment. 
Table.1 Population of ZSB SM-1 and ZSB SM-3 on Tris minimal salt medium containing different concentration of $\mathrm{Zn}\left(\mathrm{mg} \mathrm{g}^{-1}\right)$

\begin{tabular}{|c|c|c|c|c|c|c|c|c|}
\hline \multirow{3}{*}{$\begin{array}{l}\text { Zinc } \\
\text { concentration } \\
\left(\mathrm{mg} \mathrm{kg}^{-1}\right)\end{array}$} & \multicolumn{4}{|c|}{ ZSB-SM 1} & \multicolumn{4}{|c|}{ ZSB-SM 3} \\
\hline & $\begin{array}{l}1^{\text {st }} \\
\text { DAI }\end{array}$ & $\begin{array}{l}3^{\text {rd }} \\
\text { DAI }\end{array}$ & $\begin{array}{l}5^{\text {th }} \\
\text { DAI* }\end{array}$ & $\begin{array}{l}8^{\text {th }} \\
\text { DAI }\end{array}$ & $\begin{array}{l}1^{\text {st }} \\
\text { DAI }\end{array}$ & $\begin{array}{l}3^{\text {rd }} \\
\text { DAI }\end{array}$ & $\begin{array}{l}5^{\text {th }} \\
\text { DAI }\end{array}$ & $\begin{array}{l}8^{\text {th }} \\
\text { DAI }\end{array}$ \\
\hline & Mean & Mean & Mean & Mean & Mean & Mean & Mean & Mean \\
\hline 0 & 212 & 200 & 193 & 186 & 207 & 192 & 183 & 173 \\
\hline 25 & 117 & 90 & 7 & 6 & 115 & 85 & 5 & 3 \\
\hline 50 & 158 & 20 & 18 & 14 & 154 & 19 & 13 & 9 \\
\hline 100 & 189 & 100 & 9 & 8 & 181 & 97 & 6 & 2 \\
\hline 200 & 60 & 30.5 & 16 & 11 & 57 & 30 & 12 & 8 \\
\hline 300 & 31 & 26.5 & 2 & 10 & 29 & 25 & 2 & 1 \\
\hline 400 & 18 & 14 & 1.5 & 0.75 & 17 & 9 & 1 & 0 \\
\hline 500 & 11 & 6.5 & 2.5 & 1 & 11 & 4 & 0 & 0 \\
\hline Sed & 14.7 & 20.3 & 9.6 & 4.6 & 14.8 & 18.3 & 1.9 & 11.5 \\
\hline $\mathrm{CD}(\mathrm{p}=0.05)$ & 34.7 & 48.1 & 22.7 & 10.8 & 35.1 & 43.2 & 4.4 & 27.2 \\
\hline
\end{tabular}

*DAI - Day After Inoculation

Table.2 Solubilization of insoluble zinc compounds by ZSB SM-1 (broth assay)

\begin{tabular}{|c|c|c|c|c|c|c|c|}
\hline \multirow[b]{2}{*}{$\begin{array}{l}\text { Time } \\
\text { interval }\end{array}$} & \multicolumn{2}{|l|}{ Zinc oxide } & \multicolumn{2}{|l|}{ Zinc carbonate } & \multicolumn{2}{|l|}{ Zn-EDTA } & \multirow[b]{2}{*}{ Mean } \\
\hline & $\begin{array}{l}\text { Available zinc } \\
\left(\mathrm{mg} \mathrm{g}^{-1}\right)\end{array}$ & \begin{tabular}{|l|} 
Per cent \\
Solubilized
\end{tabular} & $\begin{array}{l}\text { Available zinc } \\
\left(\mathrm{mg} \mathrm{g}^{-1}\right)\end{array}$ & $\begin{array}{l}\text { Per cent } \\
\text { Solubilized }\end{array}$ & $\begin{array}{l}\text { Available zinc } \\
\left(\mathrm{mg} \mathrm{g}^{-1}\right)\end{array}$ & $\begin{array}{l}\text { Per cent } \\
\text { Solubilized }\end{array}$ & \\
\hline $\mathrm{Oh}$ & 10 & 1 & 12 & 1.2 & 9 & 0.9 & 10 \\
\hline $24 \mathrm{~h}$ & 120 & 12 & 100 & 10 & 70 & 7 & 96 \\
\hline $48 \mathrm{~h}$ & 260 & 26 & 220 & 22 & 110 & 11 & 196 \\
\hline $72 \mathrm{~h}$ & 340 & 34 & 230 & 23 & 220 & 22 & 263 \\
\hline 7 days & 390 & 39 & 350 & 35 & 360 & 36 & 366 \\
\hline 10 days & 440 & 44 & 410 & 41 & 430 & 43 & 426 \\
\hline Mean & 260 & & 220 & & 200 & & 226 \\
\hline
\end{tabular}

Table.3 Determination of $\mathrm{pH}$ in ZSB SM-1

\begin{tabular}{|l|l|l|l|l|l|l|l|}
\hline \multirow{2}{*}{ Different Zinc sources } & \multicolumn{7}{|c|}{ pH } \\
\cline { 2 - 8 } & $\mathbf{0 ~ h}$ & $\mathbf{2 4} \mathbf{~ h}$ & $\mathbf{3 6} \mathbf{~ h}$ & $\mathbf{4 8} \mathbf{~ h}$ & $\mathbf{7 2} \mathbf{~ h}$ & $\mathbf{9 6} \mathbf{~ h}$ & $\mathbf{1 2 0} \mathbf{~ h}$ \\
\hline $\mathrm{Zn} \mathrm{O}$ & 7.3 & 5.8 & 5.4 & 4.4 & 3.9 & 3.5 & 3.0 \\
\hline $\mathrm{ZnCO}_{3}$ & 7.3 & 6.0 & 5.8 & 5.6 & 5.5 & 5.0 & 4.8 \\
\hline $\mathrm{Zn}-\mathrm{EDTA}$ & 7.3 & 5.9 & 5.3 & 4.7 & 4.0 & 3.8 & 3.8 \\
\hline
\end{tabular}


Fig.1 Zinc solubilization potential of selected microbial isolates

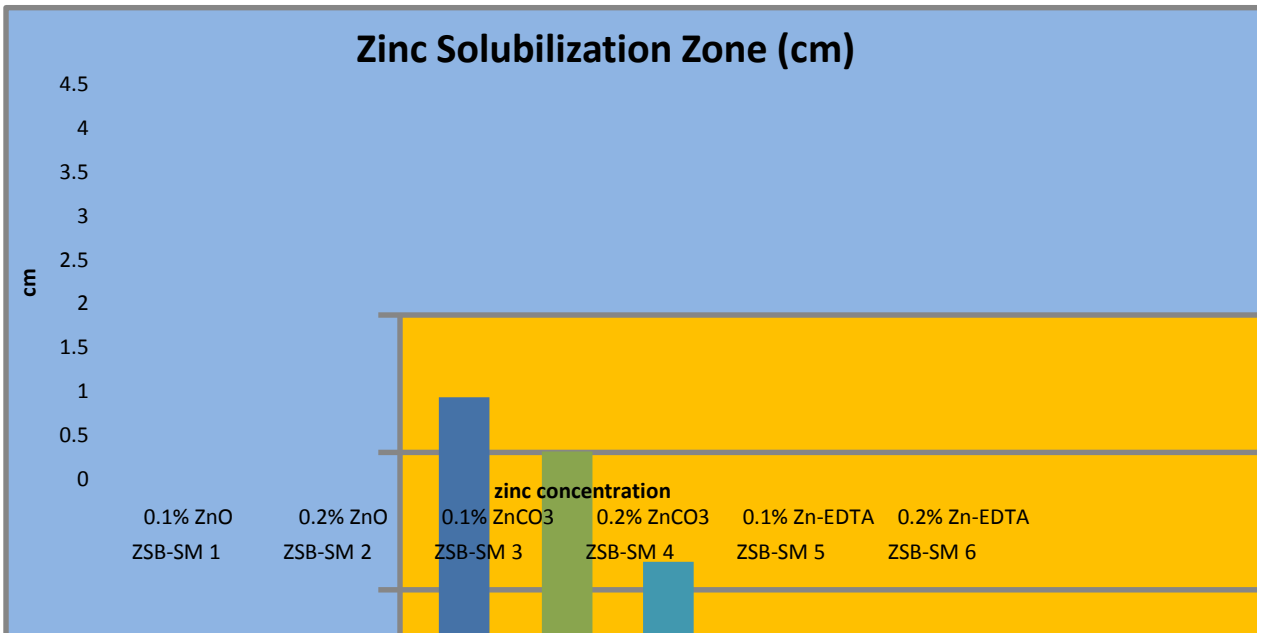

Plate.1 Development of zinc solubilzation (halo zone) by ZSB SM-1

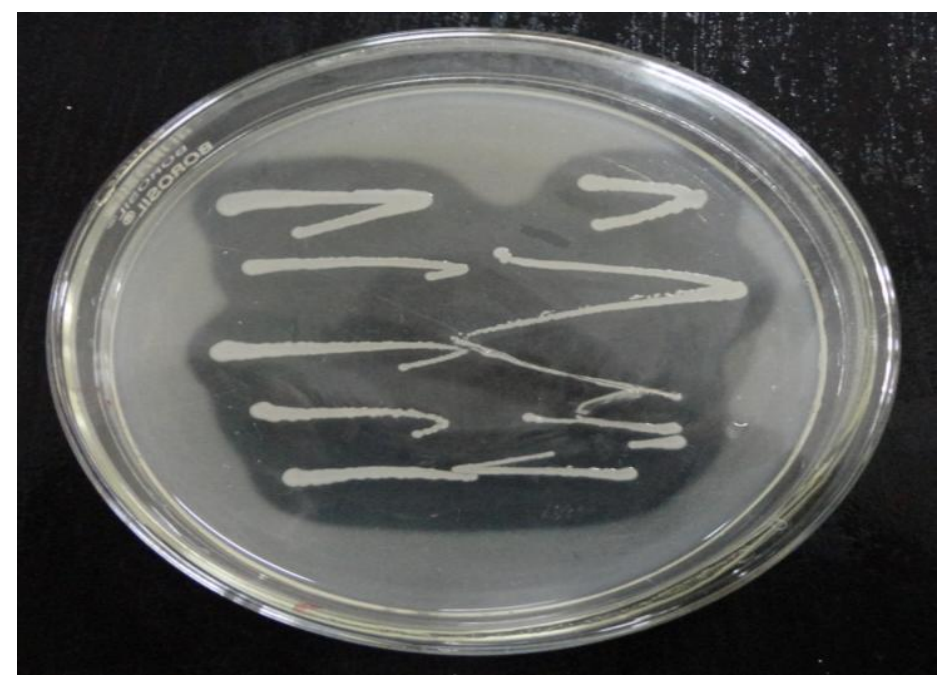

The soluble zinc was assessed by broth assay using the same chemicals. The soluble $\mathrm{Zn}$ was in an increasing trend throughout the experiment. On the $10^{\text {th }}$ day of incubation, zinc oxide, zinc carbonate and zinc EDTA solubilized 440,410 and $430 \mathrm{mg} \mathrm{g}^{-1}$ of zinc respectively (Table 2 ).

In all the three zinc sources, the zinc solubility was doubled after $48 \mathrm{~h}$ of inoculation as compared to $24 \mathrm{~h}$. Among the zinc sources, maximum solubilization was observed with zinc oxide on $10^{\text {th }}$ day (44 per cent) followed by zinc EDTA (43 per cent). Among the zinc sources, zinc oxide was solubilized better than zinc carbonate and zinc-EDTA and was significantly different from each other.

The $\mathrm{pH}$ of the medium supplemented with different zinc sources behaved differently (Table 3). In the zinc oxide and zinc EDTA added medium, the $\mathrm{pH}$ reduced gradually. Also the gradual reduction in $\mathrm{pH}$ was noticed in zinc oxide added Tris minimal salt medium broth and it reached to as low a value of 3.0 after 120 hours. 
From the results, it's clear that available zinc levels increased in incubation period. The $\mathrm{Zn}$ use efficiency of zinc sulphate is 0.32-1.5 per cent, whereas, under organic based zinc nutrition the efficiency is $2-8$ per cent.

Exogenous application of soluble $\mathrm{Zn}$ sources, similar to fertilizer application, has been advocated to various crops. This causes transformation of about 96-99 per cent of applied available $\mathrm{Zn}$ to various unavailable forms. By considering the resource constraints of the farmers and zinc fertilizers being costly, it is prudent to develop alternate technologies that are economically feasible, environmentally sustainable and zinc efficient. It is in this context, growing interest in the use of beneficial micro-organisms as bio-inoculant assumes significance to increase availability of $\mathrm{Zn}$ for assimilation by crop plants. The $\mathrm{Zn}$ thus made unavailable can be reverted back to available form by inoculating a bacterial strain capable of solubilizing it.

\section{References}

Fasim, F., N. Ahmed, R. Parsons and G.M. Gadd. 2002. Solubilization of zinc salts by a bacterium isolated from the air environment of a tannery. FEMS Microbiol. Lett., 213: 1-6.

Saravanan, V.S., Kalaiarasan, P. M. Madhaiyan, Thangaraju, M. 2007. Solubilization of insoluble zinc compounds by Gluconacetobacter diazotrophicus and the detrimental action of zinc ion $\left(\mathrm{Zn}^{2+}\right)$ and zinc chelates on root knot nematode Meloidogyne incognita. Lett, Appl Microbiol. 44: 235-241

Sharma, K. Sushil, M.P. Sharma, Aketi Ramesh, and Om P. Joshi. 2012. Characterization of Zinc-Solubilizing Bacillus isolates and their potential to influence zinc assimilation in soybean seeds. J. Microbiol. Biotechnol. 22(3), 352-359.

\section{How to cite this article:}

Mangala Devi Perumal, V. Subramanian and Sabarinathan, K.G. 2017. Evaluation of Zinc Solubilizing Potential of Maize Rhizosphere Bacterial Isolates. Int.J.Curr.Microbiol.App.Sci. 6(12): 864-869. doi: https://doi.org/10.20546/ijcmas.2017.612.093 